\title{
KEHAMILAN PADA HIPERTENSI PULMONAR BERAT
}

\author{
Starry H. Rampengan \\ Bagian Ilmu Penyakit Jantung dan Pembuluh Darah \\ Fakultas Kedokteran Universitas Sam Ratulangi Manado \\ Email: starry8888@yahoo.com
}

\begin{abstract}
Pregnancy is a very heavy burden on the cardiovascular system. Arterial-venous relaxation and blood volume increase in the early phases of conception. In embryonic phase, 5-8 weeks of pregnancy, the systemic vascular resistance decreases and the cardiac output increases until 20-30\% compared to a non-pregnant state. A pregnant patient with pulmonary hypertension has a poor prognosis and it has been strongly recommended to undergo early abortion. We report a case of pregnancy with pulmonary hypertension with unknown cause. There is a hypercoagulable state that leads to pulmonary embolism in this case. The administration of anticoagulants (heparin or warfarin) and pulmonary vasculature vasodilator drugs are early indicated. Albeit, the patients did not control regularly, therefore, she has never received these drugs until her childbirth. Prevention of pregnancy and heart problems are the main things that influnce maternal mortality. Patients who desire to continue their pregnancy must be admitted to the hospital at the second trimester of gestation and handled by multi-disciplinary specialists. Concerning the increase of maternal mortality rate termination of pregnancy is still strongly recommended to pregnant women with primary pulmonary hypertension.
\end{abstract}

Keywords: pregnancy, pulmonary hypertension, termination

\begin{abstract}
Abstrak: Kehamilan merupakan kondisi yang sangat membebani sistem kardiovaskular. Relaksasi arterial dan vena serta peningkatan volume darah dimulai pada fase-fase awal konsepsi. Pada fase embrionik 5-8 minggu pertama kehamilan resistensi sistemik vaskular menurun dan curah jantung meningkat sampai 20-30\% dibanding sebelum hamil. Prognosis buruk ditemukan pada pasien hamil dengan hipertensi pulmonal sehingga sangat direkomendasikan untuk terminasi sedini mungkin. Kami melaporkan kasus kehamilan dengan hipertensi pulmonal tanpa penyebab yang jelas. Pada kasus ini ditemukan hypercoagulable state yang dapat mengakibatkan terjadinya emboli paru. Pemberian antikoagulan (heparin atau warfarin) dan obat-obat vasodilator pembuluh darah paru diindikasikan sedini mungkin. Namun, oleh karena tidak kontrol teratur ke dokter maka sampai saat persalinanpun pasien belum pernah mendapat obat-obat jenis tersebut. Pencegahan kehamilan dan masalah jantung yang ditimbulkan merupakan dua hal utama yang memengaruhi angka kematian ibu. Pasien yang menginginkan kehamilannya diteruskan harus dirawat di rumah sakit saat usia kehamilan trimester kedua dan ditangani oleh spesialis dari multidisiplin. Terminasi kehamilan tetap merupakan pilihan utama pada pasien dengan hipertensi pulmonal primer mengingat tingginya angka kematian ibu.
\end{abstract}

Kata kunci: kehamilan, hipertensi pulmonal, terminasi

Salah satu jenis penyakit vaskular paru yaitu hipertensi pulmonar (pulmonary hypertension/PH) yang merupakan sekelompok penyakit yang ditandai proliferasi dan remodeling dinding vaskular paru sehingga terjadi peningkatan resistensi vaskular paru progresif yang selanjutnya mengakibatkan gagal jantung kanan dan 
kematian dini. Angka kejadian PH belum diketahui secara pasti, diperkirakan 1-2 kasus baru ditemukan setiap satu juta populasi umum. Kekerapan insiden perempuan lebih sering dibanding laki-laki dengan perbandingan 1,7:1.

Angka harapan hidup rata-rata saat ditegakkan diagnosis $\mathrm{PH}$ primer ialah 2,8 tahun. Usia rata-rata saat terdiagnosis $\mathrm{PH}$ yaitu 36 tahun dan umumnya fatal dalam 3 tahun jika tidak diobati. Kemajuan pesat dalam diagnosis dan pengobatan $\mathrm{PH}$ beberapa dekade terakhir ini meningkatkan angka kualitas hidup, kapasitas aktivitas, hemodinamik, dan angka kelangsungan hidup pasien $\mathrm{PH}^{4,5}$

\section{LAPORAN KASUS}

Seorang wanita FD berusia 31 tahun, dirujuk dari Puskesmas TG ke RS Kirana dengan keluhan cepat lelah.

Riwayat penyakit sekarang: Pasien dirujuk dari Puskesmas dengan keluhan cepat lelah dan didiagnosis $\mathrm{CHF}$ ec MIMS, hamil 33 minggu $\left(\mathrm{G}_{2} \mathrm{P}_{0} \mathrm{~A}_{1}\right)$. Terdapat sesak nafas saat beraktivitas ringan, ortopnea (OP), dan paroxysmal nocturnal dyspnea (PND). Nyeri dada dan berdebar disangkal sedangkan riwayat pingsan ada. Pada usia kehamilan 5 bulan, pasien mulai mengeluh-kan cepat lelah dan sesak nafas, kemudian berobat ke dokter spesialis jantung dan pembuluh darah, dilakukan ekokardiografi, dan didiagnosis sebagai hipertensi paru primer. Pasien disarankan untuk dilakukan penyadapan jantung kanan dan tindakan terminasi kehamilan, tetapi pasien tidak pernah kontrol kembali. Pasien tidak menggunakan obat kontrasepsi atau obat penurun nafsu makan, dan tidak tinggal di tempat yang tinggi. Riwayat batuk lama, batuk darah, dan sering batuk disertai panas disangkal oleh pasien. Kontrol kehamilan teratur dilakukan ke bidan dan diberikan terapi standar vitamin. Pada usia kehamilan 33 minggu, pasien masuk ke UGD RS Kirana dengan keluhan sesak yang makin berat dan makin lekas lelah, kemudian di rujuk ke Klinik Jantung Jade untuk rawat bersama.
Riwayat penyakit dahulu: Abortus spontan pada usia kehamilan 2 bulan (penyebab tidak jelas), sedangkan faktor risiko penyakit jantung koroner (PJK) tidak ditemukan.

Pada pemeriksaan fisik ditemukan pasien tampak sakit sedang dan kesadaran kompos mentis. Tekanan darah (TD) 96/72 mm Hg; denyut jantung (HR) $84 x /$ menit; pernapasan (RR) 24x/menit; suhu $36,5^{\circ} \mathrm{C}$; Saturasi (Sat) $\mathrm{O}_{2}: 70-74 \%$. Pada pemeriksaan leher didapatkan JVP $5+1 \mathrm{~cm}$ $\mathrm{H}_{2} \mathrm{O}$. Pada pemeriksaan jantung S1 normal, S2 tunggal mengeras, gallop (-), pansystolic murmur grade 3/6 LSB. Pemeriksaan abdomen membuncit, serta hati dan limpa sulit dievaluasi. Pada ekstremitas ditemu-kan clubbing $+/+$ dan sianosis $+/+$.

Gambaran foto toraks memperlihatkan CTR 52\%, aorta normal, segmen pulmonal dilatasi, pinggang jantung (+), apeks jantung downward, infiltrat (-), kranialisasi $(+)$, prunning tree $(+)$.

Gambaran EKG memperlihatkan irama Sinus, QRS rate 100x/menit, aksis RAD, gelombang $\mathrm{P}$ normal, PR interval 0,16", QRS durasi 0,08", dan RVH (+).

Hasil pemeriksaan laboratorium yaitu $\mathrm{Hb} \quad 14,0 \mathrm{~g} / \mathrm{dl}$, leukosit $7.10010^{3} / \mathrm{mm}^{3}$, hematokrit (Ht) 44\%, SGOT 27 U/L, SGPT $12 \mathrm{U} / \mathrm{L}$, ureum $24 \mathrm{mg} / \mathrm{dL} / \mathrm{BUN} 11,21$, kreatinin $0,7 \mathrm{mg} / \mathrm{dL}$, asam urat $9,2 \mathrm{mg} / \mathrm{dL}$, GDS $68 \mathrm{mg} / \mathrm{dL}$, kolesterol total $188 \mathrm{mg} / \mathrm{dL}$, HDL $30 \mathrm{mg} / \mathrm{dL}$, LDL direk $123 \mathrm{mg} / \mathrm{dL}$, trigliserida $193 \mathrm{mg} / \mathrm{dL}$, kolesterol rasio 6,27mg/dL, Na 136mEq/L, K 3,9 mEq/L.

Hasil analisis gas darah (AGDA) yaitu: $\mathrm{Hb} 14,3, \mathrm{pH} 7,41, \mathrm{pCO}_{2} 28, \mathrm{pO}_{2} 41 . \mathrm{HCO}_{3}$ $17,8, \mathrm{ABE}-5,0$, sat $\mathrm{O}_{2} 70,2 \%$.

Hasil ekokardiografi menunjukkan $\mathrm{PH}$ severe (over systemic), sistolik PAP \pm 120 mmHg, TR moderate. Tidak jelas terlihat shuntlecho gap di IAS, ASD belum dapat disimpulkan tetapi juga belum dapat disingkirkan. Kontraktilitas global LV dalam batas normal.

Diagnosis yang ditegakkan ialah $\mathrm{G}_{2} \mathrm{P}_{0} \mathrm{~A}_{1}$, hamil 33 minggu dengan hipertensi pulmonar berat ec suspek ASD sekundum dengan Eisenmenger syndrome 
dan didiagnosis banding hipertensi pulmonar primer. Pasien diberikan terapi pematangan paru untuk janin dengan kalmetason $1 \times 12 \mathrm{mg}$ selama 2 hari, dan direncanakan untuk terminasi kehamilan dengan operasi seksio sesar.

Keesokan hari pasien mengeluh perut mulas. Oleh dokter ahli kebidanan dan kandungan disarankan untuk terminasi kehamilan segera. Tanda vital normal dengan TD 110/75 mm $\mathrm{Hg}$ dan HR 93x/menit. Operasi seksio sesaria dilakukan dan bayi lahir dengan berat badan 1570 gram, panjang badan $42 \mathrm{~cm}$, serta APGAR Skor $5 / 8$ pada 1 menit dan 5 menit.

Pasien kemudian di rawat di ICU dengan terapi ceftriaxone $3 \times 1 \mathrm{~g}$ IV (didahului skin test), koritrope 0,75 $\mu \mathrm{g} / \mathrm{kg} / \mathrm{menit}$, start cedocard $1 \mathrm{mg} / \mathrm{jam}$ (titrasi), dan Syntocinon 20 IU dalam dextrosa 500 cc (tiap 12 jam). Kondisi hemodinamik belum stabil dengan TD 120/60 mmHg, MAP >80 mmHg, CVP 13 $\mathrm{mmHg}$, HR 120-130 x/menit, Sat $\mathrm{O}_{2} 65-$ $72 \%$.

Hasil laboratorium lanjut ialah: $\mathrm{Hb}$ $16,3 \mathrm{gr} / \mathrm{dl}$, leuko $15.90010^{3} / \mathrm{mm}^{3}$, Ht $51 \%$. trombosit $212.00010^{3} / \mathrm{mm}^{3}$, ureum 45 $\mathrm{mg} / \mathrm{dL}$, BUN 21,03, kreatinin 0,7 mg/dL, GDS $99 \mathrm{mg} / \mathrm{dL}$, Na $137 \mathrm{mEq} / \mathrm{L}$ ，K 5,0 $\mathrm{mEq} / \mathrm{L}, \mathrm{Cl} 107 \mathrm{mg} / \mathrm{dL}, \mathrm{Mg}$ 2,0 mg/dL, Ca ion 0,86 , dan asam laktat 1,8. Hasil AGDA yaitu: $\mathrm{pH} 7,1, \mathrm{pCO}_{2} 65, \mathrm{pO}_{2} 48, \mathrm{HCO}_{3}$ 19,5, ABE -11,8, Sat $\mathrm{O}_{2} 61,9 \%$.

Keesokan harinya, pasien dilaporkan dalam keadaan hemodinamik stabil, TD 120/51-145/60 mmHg, MAP 70-85 mmHg, CVP 10-12 mmHg, dan HR 120130x/menit. Hasil AGDA yaitu: pH 7,27, $\mathrm{pCO}_{2} 45, \mathrm{pO}_{2}$ 43, $\mathrm{HCO}_{3}$ 20,1, ABE -6,0, Sat $\mathrm{O}_{2} 65,4 \%$. Pasien diberikan terapi tambahan Lynoral 3x1, Indocid supp, sildenafil $4 \times 15 \mathrm{mg}$ per oral, start ventavis $9 \times 2,5 \mu \mathrm{g}$ per inhalasi, syntocinon $40 \mathrm{IU} / 24$ jam, dan direncanakan untuk heparinisasi.

Hasil laboratorium menunjukan: $\mathrm{Hb}$ $12,6 \mathrm{gr} / \mathrm{dl}$, leukosit $19.50010^{3} / \mathrm{mm}^{3}$, Ht $41 \%$, trombosit $40.00010^{3} / \mathrm{mm}^{3}$, PT 13,8 $(9,8-12,7)$ kontrol $(12,6)$, APTT 48,9 (2636) kontrol 32,8, TT 26,9 (14-21) kontrol 17,6, fibrinogen 300, D-Dimer 2700, ureum
$49 \mathrm{mg} / \mathrm{dL}$, BUN 22,9, kreatinin 1,2 mg/dL, dan GDS $99 \mathrm{mg} / \mathrm{dL}$. Hasil AGDA: $\mathrm{pH}$ 7,25, $\mathrm{pCO}_{2} 55, \mathrm{pO}_{2} 36, \mathrm{HCO}_{3} 23,3, \mathrm{ABE}-$ 3,8 , Sat $\mathrm{O}_{2} 55,2 \%$,

Pasien diberi terapi tambahan sildenafil 4x25 mg.

\section{BAHASAN}

PH didefinisikan sebagai suatu kondisi dimana rerata tekanan arteri pulmonar $\geq 25$ $\mathrm{mm} \mathrm{Hg}$ saat istirahat atau $\geq 35 \mathrm{~mm} \mathrm{Hg}$ saat aktivitas, dengan tekanan ujung arteri pulmonar yang normal $\leq 15 \mathrm{mmHg}$ dan peningkatan indeks resistensi vaskular paru $\geq 3 \mathrm{Um} 2$. Awalnya PH diklasifikasikan atas 2 kategori yaitu primer dan sekunder. ${ }^{4-6}$ Dinyatakan PH primer bila penyebab penyakit tidak diketahui dan dinyatakan $\mathrm{PH}$ sekunder bila disebabkan oleh beberapa penyakit antara lain penyakit jantung bawaan dan penyakit paru, atau pengaruh obat-obatan dan toksin. $5,7,8$

Hingga saat ini belum diketahui pasti bagaimana inisiasi awal terjadinya perubahan patologik vaskular pada hipertensi pulmonar walaupun berbagai teori telah banyak dikemukakan. $\mathrm{PH}$ mempunyai patobiologi multifaktor yang melibatkan berbagai jalur biokimia dan jenis sel. Peningkatan resistensi pembuluh darah paru (pulmonary vascular resistance/PVR) berhubungan dengan terjadinya vasokonstriksi, remodeling pembuluh darah paru, inflamasi, dan trombosis. Vasokonstriksi dipercaya sebagai komponen penting dalam proses terjadinya $\mathrm{PH}$. Vasokonstriksi yang berlebihan berhubungan dengan fungsi atau ekspresi abnormal saluran $\mathrm{K}^{+}$di dalam selsel otot polos dan disfungsi endotel. ${ }^{7-9}$

Disfungsi endotel merupakan proses awal yang menyebabkan berkurangnya produksi nitrik oksida (NO) dan prostasiklin serta overekspresi vasokonstriktor seperti tromboksan A2 (TxA2) dan endotelin-1 (ET-1). Ketidakseimbangan ini akan meningkatkan tonus vaskular dan menjadi promotor terjadinya remodeling vaskular. ${ }^{10}$

Proses remodeling vaskular melibatkan 
semua lapisan kompartemen dinding pembuluh darah yang ditandai oleh perubahan proliferatif dan obstruktif beberapa jenis sel antara lain endotel, otot polos, dan fibroblas. Produksi matriks ekstrasel seperti kolagen, elastin, fibronektin, dan tenasin akan meningkat pada lapisan adventisia. ${ }^{5-7,9}$

Terdapat 2 jalur mekanisme selular sebagai promotor terjadinya $\mathrm{PH}$ yaitu jalur serotoninergik dan jalur TGF- $\beta$. Terjadinya jalur serotonin diawali hipoksia yang meningkatkan ekspresi reseptor serotonin 5-HT2B dan transporter serotonin 5-HTT. Peningkatan ekspresi transporter serotonin 5-HTT bersama dengan penguat kepekaan (sensitizer) serotonin bertindak sebagai stimulus terjadinya proliferasi sel-sel otot polos dan remodeling vaskular. ${ }^{6,7,9}$ Launay et al. ${ }^{10}$ melaporkan bahwa anoreksigen seperti nor-dexfenfluramin merupakan agonis yang kuat sebagai promotor vascular-cell growth melalui jalur serotonin akibat hipoksia.

Jalur reseptor transforming growth factor $\beta$ (TGF- $\beta$ ) diawali oleh stimulus yang masih belum diketahui meningkatkan ekspresi angiopoietin-1 yang kemudian menyebabkan penekanan ekspresi bone morphogenetic protein receptor type $1 A$ (BMPR1A). Golongan reseptor TGF- $\beta$ memerlukan reseptor BMPR type 2 (BMPR2) agar dapat bekerja optimal untuk memberikan respon selular. Bentuk mutan BMPR2 dan activin-receptor-like kinase (mALK1) melalui growth-promoting Smads akan memulai terjadinya prolifersi sel otot vaskular dan remodeling vaskular. $^{7,9}$

Mekanisme ketidakseimbangan antara faktor-faktor trombogenik, mitogenik, proinflamasi, vasokonstriktor dengan faktorfaktor antikoagulan, antimitotik, dan vasodilator dianggap sebagai pencetus berlangsungnya proses vasokontriksi, proliferasi, trombosis, dan inflamasi pada mikrosirkulasi paru. ${ }^{6,8}$

\section{Diagnosis}

Diagnosis PH ditegakkan berdasarkan panduan algoritma diagnostik. Sebagian besar PH nanti diketahui saat pasien datang dengan keluhan yang nyata atau saat dilakukan penapisan pada populasi yang berisiko. Kateterisasi jantung kanan harus dilakukan pada pasien dengan dugaan $\mathrm{PH}$ untuk menegakkan diagnosis dan dokumentasi kondisi hemodinamik pembuluh darah paru. Pemeriksaan respons vasoreaktivitas akut sangat penting dilakukan saat tindakan kateterisasi jantung kanan sehingga pengobatan yang sesuai dapat diberikan. Respons akut dikatakan positif bila terjadi penurunan tekanan arteri pulmoner $>10 \mathrm{~mm} \mathrm{Hg}$ pada tekanan arteri pulmoner $<40 \mathrm{~mm} \mathrm{Hg}$ dengan curah jantung yang normal.

Setelah PH ditegakkan, kegawatan penyakit harus dinilai untuk menentukan risiko dan pengobatan yang akan diberikan. Alat bantu yang penting untuk menilai kegawatan pasien $\mathrm{PH}$ ialah penentuan kelas fungsional, kapasitas latihan, hemodinamik pulmoner, vasoreaktivitas akut, fungsi ventrikel kanan, BNP (brain natriuretic oeptide), endotelin-1, asam urat, dan kadar troponin. Pemantauan yang ketat penting dilakukan dalam tatalaksana $\mathrm{PH}^{4,8}$

Untuk memudahkah dalam menegakkan diagnosis, terdapat 4 tahapan pendekatan diagnosis $\mathrm{PH}$, antara lain: 1) Dugaan klinis PH; 2) Deteksi $\mathrm{PH}$; 3) Identifikasi kelas klinis $\mathrm{PH}$; dan 4) Evaluasi PH (tipe, kapasitas fungsional dan hemodinamik). ${ }^{4,9}$

\section{Dugaan klinis $\mathbf{P H}$}

Dugaan klinis $\mathrm{PH}$ harus dipikirkan pada semua kasus sesak napas tanpa penyakit paru atau jantung yang nyata atau pada pasien dengan latar belakang penyakit jantung atau paru namun sesak napas yang terjadi tak dapat dijelaskan berkaitan dengan penyakit tersebut.

Gejala PH juga meliputi fatigue, lemah, angina, sinkop, dan distensi

abdomen. Kelainan fisik yang didapati dari pasien PH meliputi left parasternal lift, aksentuasi komponen pulmoner bunyi 
jantung II, murmur pansistolik akibat regurgitasi trikuspid, murmur diastolik akibat insufisiensi pulmoner, dan bunyi jantung III ventrikel kanan. Distensi vena jugular, hepatomegali, edema perifer, asites, dan ekstremitas yang dingin menunjukkan keadaan lanjut dengan gagal jantung kanan. Dugaan klinis $\mathrm{PH}$ juga semakin kuat bila tanda dan gejala tersebut disertai penyakit hipertensi portal, infeksi HIV dan penyakit jantung bawaan pirau sistemik pulmoner. ${ }^{4,6,7,9}$

\section{Deteksi PH}

Setelah gejala dan tanda PH ditemukan pada pemeriksaan klinis, deteksi $\mathrm{PH}$ dilakukan dengan menggunakan pemeriksaan penunjang seperti EKG, foto toraks, dan ekokardiografi.

Pemeriksaan EKG pasien $\mathrm{PH}$ akan memperlihatkan hipertrofi ventrikel kanan, dilatasi atrium kanan, dan deviasi aksis ke kanan.

Foto toraks menunjukkan hasil yang abnormal pada $90 \%$ kasus $\mathrm{PH}$. Kelainan yang ditemukan pada foto toraks yaitu dilatasi arteri pulmonar dengan hilangnya corakan vaskular di bagian tepi. Gambaran foto toraks yang normal tidak dapat menyingkirkan mild post pulmonary hypertension, termasuk penyakit jantung kiri atau penyakit oklusi vena paru.

Ekokardiografi dan doppler transtorasik merupakan pemeriksaan yang sangat baik dalam skrining pasien dengan dugaan $\mathrm{PH}^{4,6,7,9}$

\section{Identifikasi kelas klinis $\boldsymbol{P H}$}

Terminologi Hipertensi Pulmonar Primer (HPP) pertama kali dicetuskan pada tahun 1951 setelah Dresdale et al. melaporkan data 39 pasien dengan hipertensi pulmonar yang tak dapat dijelaskan. Pada tahun 1973 WHO mengusulkan skema klasifikasi untuk $\mathrm{PH}$ yang kemudian pada tahun 1998 mengalami revisi menjadi "Klasifikasi
Evan". Dengan makin berkembangnya pengetahuan tentang HHP, klasifikasi HHP mengalami perubahan pada kongres WHO 2003 di Venice Perancis, dan yang terakhir di Dana California yang sekarang dikenal sebagai "Klasifikasi Dana Point".?

\section{Perubahan hemodinamik pada kehamilan}

Kehamilan merupakan beban yang sangat berat bagi sistem kardiovaskular, tetapi hal ini dapat ditoleransi oleh ibu hamil yang sehat. Relaksasi arterial dan vena serta peningkatan volume darah dimulai pada fase-fase awal konsepsi. Aktivasi hormonal dan zat-zat vasoaktif yang bersirkulasi menyebabkan penurunan resistensi vaskular sistemik. ${ }^{10}$ Pada fase embrionik 5-8 minggu pertama kehamilan, resistensi sistemik vaskular turun dan curah jantung meningkat mencapai 20-30\% dibanding saat sebelum hamil. Penurunan tegangan vaskular dan peningkatan compliance arteri mengakomodasi peningkatan volume darah dan mempertahankan tekanan perfusi. ${ }^{11,12}$

Frekuensi denyut jantung, venous return, end-diastolic left ventricular volumen, dan isi sekuncup berperan dalam peningkatan curah jantung. Volume darah pada usia kehamilan 8 minggu meningkat $10 \%$ dan 20-30\% pada usia kehamilan 20 minggu. Puncak peningkatan volume darah tercapai pada usia kehamilan 32-36 minggu yaitu sekitar 40-50\%, kemudian praktis tidak berubah sampai waktu persalinan aterm. ${ }^{11-13}$ Curah jantung meningkat $50 \%$ pada usia kehamilan 20-24 minggu. Pada trimester akhir, curah jantung dapat lebih jauh meningkat, menurun ringan, atau tidak berubah. $^{12-14}$

Pembesaran ruang jantung, hipertrofi miokard, remodeling jantung, dan regurgitasi katup multipel merupakan penemuan yang karakteristik pada fase akhir kehamilan. ${ }^{11,14,15}$ 
Tabel 1. Klasifikasi klinis hipertensi pulmonar yang diperbarui (Dana Point, 2008) ${ }^{9}$

1. PAH

1.1 Idiopatik

1.2 Keturunan

1.2.1 BMPR2 (bone morphogenetic protein receptor type 2)

1.2.2 ALK1 (activin receptor-like kinase type 1), endoglin (dengan atau tanpa telangiektasis hemoragik herediter)

1.2.3 Tak diketahui

1.3 Dipicu obat dan toksin

1.4 Berhubungan dengan

1.4.1 Penyakit jaringan ikat

1.4.2 Infeksi HIV

1.4.3 Hipertensi portal

1.4.4 Penyakit jantung kongenital

1.4.5 Skistosomiasis

1.4.6 Anemia hemolitik kronik

1.5 Hipertensi pulmonar menetap pada bayi

1'. Penyakit sumbatan veno-pulmonal dan/atau hemangiomatosis kapiler pulmonal

2. Hipertensi pulmonar pada penyakit jantung kiri

2.1 Disfungsi sistolik

2.2 Disfungsi diastolik

2.3 Penyakit katup

3. Hipertensi pulmonar pada penyakit paru dan/atau hipoksia

3.1 Penyakit paru obstruktif kronik

3.2 Penyakit interstitial paru

3.3 Penyakit paru lain dengan pola kombinasi restriktif dan obstruktif

3.4 Gangguan nafas saat tidur

3.5 Gangguan hipoventilasi alveolar

3.6 Paparan kronik pada ketinggian

3.7 Kelainan perkembangan

4. Hipertensi pulmonar kronik tromboembolik (Chronic thromboembolic pulmonary hypertension/CTEPH)

5. Hipertensi pulmonar dengan mekanisme multifaktor tak jelas

5.1 Gangguan hematologi: gangguan mieloproliferatif, splenektomi

5.2 Gangguan sistemik: sarkoidosis, pulmonary Langerhans cell histiocytosis,

Limfangioleiomyomatosis, neurofibromatosis, vaskulitis

5.3 Gangguan metabolik: glycogen storage disease, gaucher disease, gangguan tiroid

5.4 Lain-lain: obstruksi tumor, fibrosing mediastinitis, gagal ginjal kronik pada dialisa

Kontraksi uterus meningkatkan curah jantung sebesar $10-40 \%$ pada fase prelabour (sebelum persalinan), atau $60-80 \%$ dibanding wanita tidak hamil. Pada fase labour (persalinan) akan terjadi peningkatan venous return, volume ventrikular dan curah jantung sementara. ${ }^{14-}$ 15 Persalinan pervaginam atau operasi dengan variasi jumlah kehilangan darah, memengaruhi perubahan-perubahan pada frekuensi jantung, tekanan arteri sistemik, dan jumlah volume darah.
Frekuensi jantung, resistensi vaskular sistemik, curah jantung, dan dimensi ruang jantung mulai berkurang dalam hitungan jam postpartum. Curah jantung, isi sekuncup, kontraktilitas miokard, dan hemodinamik pulmonal mengalami perubahan kembali dalam 2 minggu postpartum. . $^{2,13,15}$

Saat kehamilan terjadi perubahan nyata pada faktor homeostasis. Protrombin time dan aPTT keduanya menurun karena peningkatan kadar faktor-faktor pembekuan 
pada jalur instrinsik dan ekstrinsik untuk pembentukan trombin. Terjadi peningkatan fibrinogen, faktor von Willebrands, dan faktor II,VII-X. Fungsi fibrinolisis juga menurun yang diakibatkan oleh menurunnya tP. Kadar protein $\mathrm{S}$ juga menurun sedangkan kadar protein $\mathrm{C}$ dan antitrombin tetap. Penekanan aliran darah balik oleh uterus dan juga lambatnya aliran darah vena mendukung terjadinya kejadian trombo-emboli pada ibu hamil. ${ }^{2,11,13,15}$

\section{Kehamilan dengan hipertensi pulmonar}

Hipertensi pulmonar primer merupakan kelainan yang jarang ditemukan menyertai kehamilan. Pengenalan awal dari keluhan-keluhan ini cukup sulit mengingat keluhan yang sama dapat timbul pada kehamilan. Prognosis yang buruk pada pasien hamil dengan hipertensi pulmonar dan kuatnya rekomendasi untuk tindakan aborsi sedini mungkin menunjukkan betapa pentingnya bagi para medis untuk mengenali penyakit ini. Angka kematian pada kehamilan ibu dengan hipertensi pulmonar bervariasi antara 30-50\%. .,15,16 $^{2}$ Kemajuan dalam bidang pengobatan medis, anestesi, obstetri, dan kegawatdaruratan belum dapat menurunkan angka kematian ibu hamil dengan hipertensi pulmonal secara bermakna. ${ }^{8,9,17,18}$

Salah satu masalah penting yang dihadapi oleh para medis ialah tidak semua ibu hamil bersedia untuk dilakukan terminasi kehamilan. Kasus demikian memerlukan beberapa pendekatan pada semua fase kehamilan dan kondisi ibu perlu dimonitor dan ditatalaksana dengan baik. Aktivitas fisik harus diminimalisasi untuk mencegah meningkatnya beban sirkulasi. Untuk optimalisasi monitoring, pasien harus dirawat di rumah sakit setelah usia kehamilan 20 minggu atau lebih awal bila timbul keluhan. ${ }^{17,19,20}$

Pada masa kehamilan, perlu dipertimbangkan pemberian obat-obat vasodilator pembuluh darah paru. NO inhalasi termasuk vasodilator pulmonar yang poten. Terdapat beberapa laporan mengenai keberhasilan penggunaannya pada saat persalinan dan periode peripartum. Epoprosterenol iv secara kontinyu terbukti menurunkan resistensi vaskular paru dan memperbaiki fungsi ventrikel kanan pada beberapa kasus serial dengan hipertensi pulmonal primer maupun sekunder. Efek menguntungkan lainnya berupa vasodilatasi selektif vaskular paru, inhibisi agregasi platelet, dan atau vaskular remodelling. $\mathrm{PGI}_{2}$ aerosol dan iloprost aerosol dikatakan lebih efektif dalam menurunkan tekanan arteri pulmonal jika dibandingkan epoprosterenol iv dan inhalasi NO pada pasien dengan hipertensi pulmonar primer ataupun sekunder. ${ }^{11,20}$

Pemberian obat antitrombotik pada ibu hamil terus mengundang kontroversi, tetapi pencegahan terhadap kejadian tromboemboli secara umum direkomendasikan pada pasien hipertensi pulmonar. Strategi tatalaksana ini berdasarkan hasil observasi terjadinya peningkatan trombogenesis pada semua tipe penyakit vaskular paru. Mekanismenya dipostulasikan berupa inflamasi vaskular, proliferasi sel, disfungsi endotel dengan abnormalitas faktor von Willebrand, peningkatan aktivasi leukosit dan platelet, serta berkurangnya fibrinolisis. ${ }^{11,20}$

Pada saat kehamilan, penentuan cara persalinan apakah per vaginam atau seksio sesaria secara restrospektif juga menentukan prognosis dari ibu. Dikatakan bahwa angka kematian pada persalinan per vaginam mencapai $30 \%$ sedangkan pada seksio sesaria mencapai $50 \%$. Hal ini mungkin disebabkan karena seksio sesaria dilakukan pada ibu hamil yang mengalami ketidakstabilan hemodinamik.

Pemberian epoprosterenol iv selama persalinan pernah dilaporkan pada kasus penurunan curah jantung dengan hasil tercapainya kestabilan hemodinamik pada ibu. NO intra-operatif juga dapat digunakan untuk menurunkan tekanan arteri pulmonar. Pemilihan anestesi juga menentukan outcome ibu; dapat diberikan lumbal epidural block, atau intrathecal opiate dengan pudendal block pada persalinan per 
vaginam. Pada seksio sesaria, regional block sangat berpotensi membahayakan karena dapat menurunkan preload ventrikel kanan. Anestesia umum lebih baik digunakan untuk mengefektifkan preload ventrikel kanan. ${ }^{11,20}$

Akibat terjadinya stres dan perubahan hemodinamik yang berhubungan dengan persalinan dan masa postpartum, monitoring hemodinamik dan EKG diindikasikan pada semua pasien. Curah jantung, tekanan arteri pulmonar, dan tekanan darah sistemik harus dikontrol secara teratur saat persalinan. Obat antikoagulan dapat diberikan dalam waktu 48 jam postpartum. Saat postpartum, pemberian obat vasodilator dapat diteruskan. Pernah dilaporkan penggunaan iloprost nebuliser dan infus prostasiklin. 11,20

Pemberian oksitosin infus dapat menurunkan resistensi vaskular sistemik tetapi dapat juga meningkatkan resistensi vaskular paru, yang mengakibatkan penurunan curah jantung. ${ }^{21-23}$

Karena angka mortalitas ibu yang tinggi pada kehamilan dengan hipertensi pulmonar primer, maka terminasi kehamilan atau pencegahan terjadinya konsepsi menjadi hal yang sangat penting. Pemilihan penggunaan kontrasepsi sangat penting yaitu dengan cara pemasangan alat kontrasepsi dalam rahim atau tubektomi. Penggunaan kontrasepsi jenis lain sangat tidak dianjurkan mengingat masih adanya kemungkinan terjadinya kehamilan. ${ }^{21-23}$

Masalah yang timbul pada fetus in utero yaitu persalinan prematur yang berdampak peningkatan angka kematian bayi. Juga pernah dilaporkan kematian neonatus akibat malformasi jantung. ${ }^{21-23}$

Telah dilaporkan sebuah kasus kehamilan dengan hipertensi pulmonal yang tak jelas penyebabnya apakah primer ataupun sekunder. Kelainan katup telah disingkirkan dengan pemeriksaan ekokardiografi. Penyakit gangguan jaringan ikat disingkirkan melalui anamnesis tidak terdapatnya riwayat ruam pada ibu, nyeri sendi, fungsi ginjal dan hepar yang normal, dan nilai $\mathrm{Hb}$ serta jumlah leukosit dan trombosit yang normal pre-labour. ${ }^{2,15,16}$

Penyakit jantung kongenital yang dapat meningkatkan aliran darah ke paru seperti PAPVD dan VSD telah dapat disingirkan, tetapi ASD belum sepenuhnya dapat ditiadakan. Selama ini pasien jarang mengalami batuk dan panas. Selain itu, pemeriksaan laboratorium tidak menunjukkan peningkatan jumlah leukosit, dan pemeriksaan foto toraks tidak memperlihatkan infiltrat dan pelebaran ruang interkostal sehingga penyakit paru kronik obstruktif dapat disingkirkan. Pasien juga tidak tinggal pada daerah ketinggian. Hipertensi portal telah disingkirkan dengan hasil pemeriksaan enzim SGOT dan SGPT yang normal, dan tidak terdapatnya sklera yang ikterik. $^{2,15,16}$

Perlu juga dilakukan pemeriksaan lanjut, yaitu: pemeriksaan laboratorium ANA dan CD4 untuk menyingkirkan HIV; ventilation-perfusion lung scan untuk mendeteksi adanya trombus pada arteri pulmonar; dan pemeriksaan feses untuk menyingkirkan adanya obstruksi parasit.

Pada kehamilan terdapat suatu perubahan keadaan yaitu hypercoagulable state yang dapat menyebabkan terjadinya emboli paru yang sangat mungkin ditemukan pada pasien ini. Walaupun pemberian antikoagulan berupa heparin atau warfarin pada trimester ke-2 diindikasikan pada kasus ini, ${ }^{2,15-16,21,22}$ pasien ini belum pernah mendapatkan terapi tersebut.

Pemberian obat-obat vasodilator pembuluh darah paru juga diindikasikan sedini mungkin dalam masa kehamilan. ${ }^{11,20}$ Oleh karena tidak kontrol teratur maka sampai saat persalinan pasien ini belum pernah mendapat obat jenis tersebut.

\section{SIMPULAN}

Pencegahan kehamilan dan masalah jantung yang ditimbulkan tetap merupakan hal utama yang menentukan angka kematian ibu. Pasien yang menginginkan kehamilannya dilanjutkan harus dirawat di rumah sakit saat usia kehamilan trimester kedua dan ditangani oleh multidisiplin 
spesialis.

Walaupun perkembangan ilmu kedokteran telah mengalami kemajuan pesat, tetapi mengingat tetap tingginya angka kematian ibu terminasi tetap merupakan terapi utama pada kasus kehamilan dengan hipertensi pulmonar primer.

\section{DAFTAR PUSTAKA}

1. Ray P, Murphy GJ, Shutt LE. Recognition and management of maternal cardiac disease in pregnancy. British Journal of Anaesthesia. 2004;93(3):428-39.

2. Weiss BM, Hess OM. Pulmonary vascular disease and pregnancy: current controversies, management strategies, and perspectives. European Heart Journal. 2000;21:104-15.

3. Stewart R, Tuazon D, Olson G, Duarte AG. Pregnancy and primary pulmonary hypertension. Chest. 2001;119:973-5.

4. Levine DJ. Diagnosis and management of pulmonary arterial hypertension: implications for respiratory care. Respiratory Care. 2006;51(4):368-81.

5. Armstrong AC, Bandeira ÂMP, Correia LCL, Melo HCO, Silveira CAM, Albuquerque E, et al. Pulmonary artery pressure, gender, menopause, and pregnancy in schistosomiasisassociated pulmonary hypertension. Arq Bras Cardiol. 2013;101(2):154-9.

6. Montani $D$, Günther $S$, Dorfmüller P, Perros F, Girerd B, Garcia G, et al. Pulmonary arterial hypertension. Orphanet J Rare Dis. 2013;8(97):1-28.

7. Galie'N, Hoeper MM, Humbert M, Torbicki A, Vachiery JL, Barbera JA, et al.The task force for the diagnosis and treatment of pulmonary hypertension of the European Society of Cardiology (ESC) and the European Respiratory Society (ERS), endorsed by the International Society of Heart and Lung Transplantation (ISHLT). Guidelines for the diagnosis and treatment of pulmonary hypertension. Eur Heart J. 2004;25:2243-78.

8. Kneussl MP, Lang IM, Brenot FP. Medical management of primary pulmonary hypertension. Eur Respir J. 1996;9:2401-9.

9. Galie' N, Hoeper MM, Humbert M, Torbicki A, Vachiery JL, Barbera
JA, et al. The Task Force for the Diagnosis and Treatment of Pulmonary Hypertension of the European Society of Cardiology (ESC) and the European Respiratory Society (ERS), endorsed by the International Society of Heart and Lung Transplantation (ISHLT). Guidelines for the diagnosis and treatment of pulmonary hypertension. Eur Heart J. 2009;30:2493-537.

10. Launay JM, Herve' $P$, Callebert J, Mallat IZ, Collet C, Doly S. Serotonin 5-HT2B receptors are required for bone-marrow contribution to pulmonary arterial hypertension.Blood. 2012;119(7):1772-80.

11. Leuchte HH, Schwaiblmair M, Baumgartner RA, Neurohr CF, Kolbe T, Behr J. Hemodynamic response to sildenafil, nitric oxide, and iloprost in primary pulmonary hypertension. Chest. 2004:125:580-6. [PubMed: 14769741]

12. Monnery L, Nanson J, Charlton G. Primary pulmonary hypertension in pregnancy; a role for novel vasodilators. British Journal of Anaesthesia. 2001;87(2):295-8.

13. Roth A, Elkayam U. Acute Myocardial Infarction Associated With Pregnancy.J Am Coll Cardiol. 2008;52;171-180.

14. Frost AM. The pregnant patient with pulmonary artery hypertension. MEJ Anesth. 2011;21(2):99-108.

15. Rosengarten D, Kramer MR. Pulmonary hypertension and pregnancy: management and outcome. J Pulmon Resp Med. 2013;S4(4):1-5.

16. Bassily-Marcus M, Yuan C, Oropello J, Manasia A, Kohli-Seth R, Benjamin E. Review article pulmonary hypertension in pregnancy: critical care management. Pulmonary Medicine. 2012;2012:709407.doi. Available from: http://dx.doi.org/10.1155/2012/7094071 -10 .

17. Thorne S, Nelson-Piercy C, MacGregor A, Gibbs S, Crowhurst J, Panay N, et al. Pregnancy and contraception in heart disease and pulmonary arterial hypertension. J Fam Plann Reprod Health Care. 2006;32(2):75-81.

18. Elwing JM, Panos RJ. Pregnancy and pulmonary arterial hypertension. Intech. 2011;16:289-304. 
19. Demerouti E, Manginas A, Rammos S, Athanassopoulos G, Karatasakis G, Pavlides G. Postpartum pulmonary arterial hypertension: two cases covering a wide spectrum of presentations. Hellenic J Cardiol. 2012;53:472-5.

20. Elliot CA, Stewart P, Webster VJ, Mills GH, Hutchinson SP, Howarth ES et al.The use of iloprost in early pregnancy in patients with pulmonary arterial hypertension. Eur Respir J. 2005;26:168-73.

21. Bonnin M. Severe pulmonary hypertension during pregnancy. Mode of delivery and anesthetic management of 15 consecutive cases. Anesthesiology. 2005;102:1133-7.

22. Matshela MR. Pulmonary hypertension in pregnancy and its prognostic implications. PVRI Chronicle. JulyDecember 2014;1(2):1-5.

23. Jackson GM, Dildy GA, Varner MW, Clark SL. Severe pulmonary hypertension in pregnancy following successful repair of ventricular septal defect in childhood. Obstetic Gynecol. 1993;82:680-2. 
Rampengan, Kehamilan pada Hipertensi PulmonarBerat... 202 